\title{
Methionine aminopeptidase- 2 is a pivotal regulator of vasculogenic mimicry
}

\author{
SHOTA SHIMIZU, RYOTA KAWAHARA and SIRO SIMIZU \\ Department of Applied Chemistry, Faculty of Science and Technology, Keio University, Yokohama 223-8522, Japan
}

Received October 26, 2021; Accepted November 30, 2021

DOI: $10.3892 /$ or.2021.8242

\begin{abstract}
Vasculogenic mimicry (VM) is the formation of a blood supply system that confers aggressive and metastatic properties to tumors and correlates with a poor prognosis in cancer patients. Thus, the inhibition of VM is considered an effective approach for cancer treatment, although such a mechanism remains poorly described. In the present study, we examined methionine aminopeptidase-2 (MetAP2), a key factor of angiogenesis, and demonstrated that it is pivotal for VM, using pharmacological and genetic approaches. Fumagillin and TNP-470, angiogenesis inhibitors that target MetAP2, significantly suppressed VM in various human cancer cell lines. We established MetAP2-knockout (KO) human fibrosarcoma HT1080 cells using the CRISPR/Cas9 system and found that VM was attenuated in these cells. Furthermore, re-expression of wild-type MetAP2 restored VM in the MetAP2-KO HT1080 cells, but the substitution of D251, a conserved amino acid in MetAP2, failed to rescue the VM. Collectively, our results demonstrate that MetAP2 is critical for VM in human cancer cells and suggest fumagillin and TNP-470 as potent VM-suppressing agents.
\end{abstract}

\section{Introduction}

Tumor angiogenesis is a well-known mechanism by which blood is supplied to promote tumor progression through oxygen and nutrient intake $(1,2)$. Several angiogenesis inhibitors have

Correspondence to: Professor Siro Simizu, Department of Applied Chemistry, Faculty of Science and Technology, Keio University, 3-14-1 Hiyoshi, Kohoku-ku, Yokohama 223-8522, Japan

E-mail: simizu@applc.keio.ac.jp

Abbreviations: DMEM, Dulbecco's modified Eagle's medium; EMT, epithelial-to-mesenchymal transition; eIF2 $\alpha$, eukaryotic translation initiation factor- $2 \alpha$; FUM, fumagillin; HIF, hypoxia-inducible factor; MetAP2, methionine aminopeptidase-2; MMP, matrix metalloproteinase; TNP, TNP-470; VM, vasculogenic mimicry

Key words: angiogenesis inhibitor, cell migration, fumagillin, methionine aminopeptidase-2, MetAP2, TNP-470, vasculogenic mimicry been developed, but some have been unable to overcome drug resistance and provide sufficient benefit for cancer patients (3). In certain cases, tumors can grow even when angiogenesis is inhibited, suggesting the existence of distinct blood supply pathways.

Recent studies have indicated that vasculogenic mimicry (VM), the formation of blood vessel-like structures only by cancer cells, constitutes an alternative blood supply system in malignant tumors $(4,5)$. VM has been reported in a wide variety of malignancies, including melanoma, breast cancer, and lung cancer, and this phenomenon is considered to contribute to tumor growth and metastasis (4,6-8). Although some reports indicate that VM correlates with reduced overall survival in cancer patients $(9,10)$, the underlying mechanisms of VM have not been detailed completely-an urgent area of study as a potential therapeutic target in cancer.

An association between angiogenesis and VM has been implicated in the past 2 decades. For example, the transcription factor hypoxia-inducible factor (HIF)- $1 \alpha$ is activated under hypoxia. The increase in HIF-1 $\alpha$ activity promotes tumor-associated angiogenesis in solid tumors by stimulating the transcription of angiogenesis-related genes (11); furthermore, HIF-1 $\alpha$ was found to mediate epithelial-to-mesenchymal transition (EMT) and VM by upregulating LOXL2 in hepatocellular carcinoma (12). Matrix metalloproteinase (MMP)-9 facilitates angiogenesis during carcinogenesis (13), and many studies have reported that high expression of MMP-9 correlates positively with VM in many types of cancer cells $(14,15)$. These studies suggest that the mechanisms of VM resemble in part those of angiogenesis and are regulated by certain angiogenic factors.

N-terminal methionine processing of nascent proteins is a critical event in cells for maintaining the proper growth of organisms, and methionine aminopeptidases (MetAPs) are central in the removal of N-terminal methionine $(16,17)$. MetAPs consist of 2 members: MetAP1 and MetAP2. In contrast to MetAP1, MetAP2 is associated with other molecules, in addition to having aminopeptidase activity, modulating protein synthesis by regulating the phosphorylation of eukaryotic initiation factor-2 $\alpha$ (eIF2 $\alpha$ ) (18). These studies indicate that MetAP2 has several functions and is crucial for cell growth.

Fumagillin (FUM) was first isolated from Aspergillus sp. as an antibiotic (19), and FUM and its derivative, TNP-470 (TNP), have been used as potent angiogenesis inhibitors $(20,21)$. 
Because these inhibitors commonly target MetAP2 $(22,23)$, angiogenesis has been considered to be regulated by MetAP2. In point of fact, a disruption in MetAP2 suppresses the proliferation of endothelial cells and effects an abnormal vasculature in embryos (24), suggesting that MetAP2 promotes tumor growth by mediating angiogenesis. Moreover, tumor cells such as mesothelioma and colorectal, breast, and lung adenocarcinoma, highly express MetAP2, and ectopic expression of MetAP2 stimulates fibrosarcoma cell proliferation (25-27).

Although the functions of MetAP2 in endothelial cells are well known, that of MetAP2 in tumor cells has not been determined. A MetAP2 inhibitor was found to suppress proliferation in a subset of tumor cells and in endothelial cells (28), suggesting that MetAP2 regulates cell growth in cancers. However, van der Schaft et al reported that TNP does not prevent VM in melanoma cells, despite it inhibiting endothelial tube formation at the same concentration (29). Collectively, MetAP2 inhibitors suppress the growth and tube formation of endothelial cells, but their inhibitory effects on VM in tumor cells has not been examined.

In the present study, we used human fibrosarcoma HT1080 cells, which have high potential for VM, to determine the relationship between MetAP2 and VM. We found that MetAP2 inhibitors significantly suppressed VM in the HT1080 cells. Using the CRISPR/Cas9 system, we established MetAP2-knockout (KO) HT1080 cells and observed that deletion of MetAP2 inhibited VM. Re-expression of wild-type (wt) MetAP2 recovered VM, but an inactive mutant form of MetAP2 failed to effect VM in MetAP2-KO cells. Moreover, TNP inhibited VM in several tumor cell lines. These results indicate that the angiogenic factor MetAP2 is pivotal in VM and suggest that treatment with a MetAP2 inhibitor is an effective strategy against VM-positive tumors.

\section{Materials and methods}

Cell culture. Human fibrosarcoma HT1080 (Japanese Collection of Research Bioresources Cell Bank, Osaka, Japan) and human breast cancer MDA-MB-231 cells (gifted by Professor Masakazu Toi, Kyoto University Graduate School of Medicine, Kyoto, Japan) were cultured in Dulbecco's modified Eagle's medium (DMEM; Nissui Pharmaceutical Co., Ltd.) that was supplemented with $5 \%(\mathrm{v} / \mathrm{v})$ fetal bovine serum (FBS), $100 \mathrm{U} / \mathrm{ml}$ penicillin $\mathrm{G}, 100 \mathrm{mg} / \mathrm{l} \mathrm{kanamycin,} 600 \mathrm{mg} / \mathrm{l}$ L-glutamine, and $2.25 \mathrm{~g} / 1 \mathrm{NaHCO}_{3}$ at $37^{\circ} \mathrm{C}$ in a humidified incubator with $5 \% \mathrm{CO}_{2}$. Human melanoma SK-MEL-28 and human breast cancer T47D cells were obtained from RIKEN BioResource Center and cultured in DMEM that was supplemented with $8 \%$ (v/v) FBS, $100 \mathrm{U} / \mathrm{ml}$ penicillin $\mathrm{G}, 100 \mathrm{mg} / \mathrm{l}$ kanamycin, $600 \mathrm{mg} / \mathrm{l} \mathrm{L-glutamine,} \mathrm{and} 2.25 \mathrm{~g} / 1 \mathrm{NaHCO}_{3}$ at $37^{\circ} \mathrm{C}$ in a humidified incubator with $5 \% \mathrm{CO}_{2}$.

Reagents. TNP-470 (Cayman Chemical) and fumagillin (FUJIFILM Wako Pure Chemical Corp.) were dissolved in dimethyl sulfoxide (DMSO). The concentrations of the stock solution (TNP and FUM) were $10 \mathrm{mg} / \mathrm{ml}$. In all experiments, the level of DMSO was $0.1 \%$ in the vehicle control.

In vitro VM assay. HT1080, SK-MEL-28, T47D, and MDA-MB-231 cells, suspended in culture medium, were seeded at $1.6 \times 10^{4}$ cells/well in a 96 -well plate that was precoated with $40 \mu \mathrm{l} /$ well Matrigel (Corning Inc.). The seeded cells were cultured at $37^{\circ} \mathrm{C}$ and photographed under a phase-contrast microscope (Leica DMi1; Leica Microsystems $\mathrm{GmbH}) 3 \mathrm{~h}$ later.

MTT assay. MTT assay was performed to measure cell proliferation rates with thiazolyl blue tetrazolium bromide (Merck KGaA). Cells were seeded at $2.0 \times 10^{3}$ cells/well in a 96-well plate and cultured for $24 \mathrm{~h}$. Then, thiazolyl blue tetrazolium bromide was added to the cells and incubated for $4 \mathrm{~h}$ at $37^{\circ} \mathrm{C}$. After incubation, the medium was removed, and the MTT formazan product was dissolved with $100 \mu 1$ DMSO. The levels of these products were measured by absorbance at $570 \mathrm{~nm}$.

WST assay. WST assay was performed to measure living cell numbers with the Cell Counting Kit-8 (FUJIFILM Wako Pure Chemical Corp.). Cells were seeded at $1.6 \times 10^{4}$ cells/well in a 96-well plate that was precoated with $40 \mu \mathrm{l} /$ well Matrigel and cultured for $1 \mathrm{~h}$ at $37^{\circ} \mathrm{C}$. Then, the Cell Counting Kit- 8 was added to the cells. After incubation for $2 \mathrm{~h}$ at $37^{\circ} \mathrm{C}$, absorbance at $450 \mathrm{~nm}$ was measured.

Generation of MetAP2-KO cell lines by CRISPR/ Cas9. MetAP2-KO HT1080 cells were established using the CRISPR/Cas9 system as previously described (30). To avoid off-target effects, we used the pSpCas9n(BB)-2A-Puro (PX462) V2.0 plasmid (Addgene), a gift from Feng Zhang, to coexpress Cas9n [D10A nickase mutant (31)]. Target sequences were designed within exon 1 of human MetAP2, with the following oligonucleotides: forward 1,5'-CACCGGGAAGAA GGAGCTGCCTCTA-3' and reverse 1, 5'-AAACTAGAGGCA GCTCCTTCTTCCC-3'; forward 2, 5'-CACCGCTGGATC CAGGTCGCCATTC and reverse 2, 5'-AAACGAATGGCG ACCTGGATCCAGC-3'.

Each pair of oligonucleotides was annealed and then inserted into the $B b s I$ restriction site of the Cas9n expression vector. HT1080 cells were cotransfected with these plasmids and selected with $2 \mu \mathrm{g} / \mathrm{ml}$ puromycin dihydrochloride (Merck KGaA) for 2 weeks. After selection, clonal cell lines were isolated by limiting dilution method, and KO of MetAP2 was confirmed by western blot analysis.

Western blot analysis. We performed western blot analysis as previously described (32-35). Cells were cultured in a 60-mm dish and lysed in lysis buffer [50 mM Tris-HCl, $\mathrm{pH} 7.5$, $150 \mathrm{mM} \mathrm{NaCl}, 0.1 \%(\mathrm{w} / \mathrm{v})$ sodium dodecyl sulfate, $1 \%(\mathrm{v} / \mathrm{v})$ Triton X-100, 1\% (w/v) sodium deoxycholate, and $1 \mathrm{mM}$ phenylmethylsulfonyl fluoride] at $4^{\circ} \mathrm{C}$ with sonication. The cell lysates were centrifuged at $15,000 \mathrm{x}$ g for $10 \mathrm{~min}$ to eliminate debris. Protein concentrations were measured by Coomassie Brilliant Blue G-250 staining (Bio-Rad Laboratories), and loading buffer [350 mM Tris-HCl, pH 6.8, 30\% (w/v) glycerol, $0.012 \%(\mathrm{w} / \mathrm{v})$ bromophenol blue, 6\% (w/v) SDS and $30 \%(\mathrm{v} / \mathrm{v}) 2$-mercaptoethanol] was added to each lysate. After electrophoresis, proteins (15 $\mu \mathrm{g} / \mathrm{lane})$ were transferred to polyvinylidene fluoride membranes and immunoblotted with anti-MetAP2 (\#12547S; Cell Signaling Technology, Inc.) or anti- $\alpha$-tubulin (\#T5168; Merck KGaA). Signals were detected 
by ECL using Western Lightning Plus-ECL (PerkinElmer, Inc.) or Immobilon Western Chemiluminescent HRP substrate (Merck KGaA).

MetAP2-rescued cell lines. Human MetAP2 cDNA was amplified from an HT1080 cell cDNA library using the following primers: forward, 5'-TTTTCTCGAGATGGCGGGTGTGGA GGAGGTAGC-3' and reverse, 5'-TTTTACGCGTTTAAT AGTCATCTCCTCTGCTG-3'.

To prevent recognition and cleavage by Cas9n, we designed Cas9n-resistant MetAP2 cDNA by codon optimization with no amino acid substitutions, using the following primers: forward, 5'-ATAGAGAGGAGGGGGCCGCTT CCACAGCTGAGGAAGCAGCCAAGAAAAAAAGAC-3' and reverse, 5'-CATCGGGGTCAAGATCTCCGTTTAAG TGGCTCCCGGAGGCCGCTACCTC-3'. The resulting DNA was subcloned into the XhoI/MluI sites of pCI-neo (Promega Corp.).

A point mutation (D251A) was introduced into the MetAP2 cDNA by site-directed mutagenesis using the following primers: forward, 5'-ATCTGTAAAATAGCCTTTGGAACA CATATAAGTGGTAGG-3' and reverse, 5'-GTGTTCCAA AGGCTATTTTACAGATGTCATCATACTGTAATACTG-3'. The resulting DNA was subcloned into the $X h o \mathrm{I} / M l u \mathrm{I}$ sites of pCI-neo.

MetAP2-KO HT1080 cells were transfected with these plasmids and selected with $500 \mu \mathrm{g} / \mathrm{ml} \mathrm{G} 418$ (FUJIFILM Wako Pure Chemical Corp.) for 2 weeks. After selection, the clonal cell lines were isolated by limiting dilution method, and re-expression of MetAP2 was confirmed by western blot analysis.

Wound-healing assay. Cells were seeded in 12-well plates at $1.5 \times 10^{5}$ cells/well and cultured for $24 \mathrm{~h}$. One hundred percent of the cells were wounded using a $200-\mu$ l pipette tip (Watson). After being washed twice with PBS to remove floating cells, the cells were cultured in serum-free DMEM as described previously (36). Photographs of 4 independent areas were taken, and the migrated areas were quantified using ImageJ 1.52q (National Institutes of Health) (37).

Trypan blue dye exclusion assay. Suspended cells were mixed with trypan blue solution (Merck KGaA), and unstained (alive) and blue (dead) cells were counted on a hemocytometer (ERMA) as previously described (38).

Statistical analysis. Statistical analysis was performed using SPSS Statistics 27.0 [International Business Machines (IBM) Corp.]. Unpaired one-way ANOVA with Dunnett's multiple comparisons test was performed to confirm statistical significance, and the results are expressed as means \pm standard deviation (SD). P-values $<0.05$ were considered to be statistically significant.

\section{Results}

Fumagillin and TNP-470 suppress VM in HT1080 cells. Based on its function as a methionine aminopeptidase, we continuously treated tumor cell lines with inhibitors to evaluate the effects of MetAP2 on VM. As shown in Fig. 1A, on Day 0, tumor cells were seeded in plates and cultured for $24 \mathrm{~h}$. On
Days 1,2, and 3, the culture media was changed, and cells were treated with vehicle control (DMSO) or drugs (FUM or TNP). On Day 4, we suspended the cells and seeded them on Matrigel-coated well plates in the presence of drugs, thus inhibiting MetAP2 activities.

To determine the inhibitory effects of FUM and TNP on VM, we used HT1080 cells in which VM was previously found to occur in a short-time culture (30). We administered these inhibitors to HT1080 cells in which VM and performed in vitro $\mathrm{VM}$ assay, as described above (Fig. 1A). FUM and TNP suppressed VM in HT1080 cells dose-dependently ( $\mathrm{IC}_{50}$ of FUM: $0.80 \mathrm{ng} / \mathrm{ml}, \mathrm{IC}_{50}$ of TNP: $0.69 \mathrm{ng} / \mathrm{ml}$; Fig. $1 \mathrm{~B}$ and C). Because these inhibitors can be cytotoxic, we confirmed living cell numbers on Matrigel matrices. By WST assay, the number of living cells among the control and inhibitor-treated cells did not change significantly (Fig. S1A and B), indicating that the inhibition of VM by FUM and TNP was not due to their cytotoxicity. We further analyzed their effects by monitoring short-term and long-term VM. Whereas control cells formed tube structures from $3 \mathrm{~h}$ that were maintained until $24 \mathrm{~h}$ after seeding, FUM and TNP significantly disrupted VM at all periods (Fig. 1D and E). These results suggest that inhibition of MetAP2 causes a significant decrease in VM in HT1080 cells.

MetAP2 is pivotal for VM in HT1080 cells. Because MetAP2 inhibitors impaired VM in HT1080 cells, we verified that MetAP2 regulates VM using a genetic approach, generating MetAP2-KO HT1080 cells by CRISPR/Cas9 (Fig. 2A). As expected, network formation was significantly inhibited upon KO of MetAP2 (Fig. 2B and C). To confirm this effect, we performed rescue experiment in HT1080 cells by using wild-type and enzymatically-inactive MetAP2. A previous study indicated that FUM covalently targets $\mathrm{H} 231$ residue of MetAP2 and inactivates enzymatic activity of MetAP2 (39). H231N mutation lacks catalytic activity of MetAP2 (39), however overexpression of this mutant causes serious cell growth inhibition in HT1080 cells (27), therefore, we replaced other crucial residues of MetAP2. D251 residue locates conserved metal-binding site of MetAP2 and that replacement of this aspartic acid is considered to affect its catalytic activity. Thus, we re-expressed the D251A mutant form (DA) of MetAP2 and wild-type (wt) MetAP2 in MetAP2-KO HT1080 cells (Fig. 2D). As a result, whereas wild-type MetAP2 recovered VM, D251A MetAP2 failed to enhance network formation (Fig. 2E and F), indicating that MetAP2 regulates VM. Although the activity of MetAP2 is crucial for VM, the expression of wild-type or D251A MetAP2 did not significantly affect the proliferation of HT1080 cells (Fig. S2). These results suggest that MetAP2 promotes VM without altering cell proliferation.

Because VM is associated with the high metastatic phenotype of tumor cells, we assessed cell migration in MetAP2-KO HT1080 cells. By wound-healing assay, KO of MetAP2 significantly reduced cell migration compared with the mock cells (Fig. 3A and B). Consistent with this result, FUM and TNP decreased HT1080 cell migration (Fig. 3C and D). These results indicate that MetAP2 is important for cell migration and that MetAP2-mediated VM is upregulated through the promotion of cell motility. 

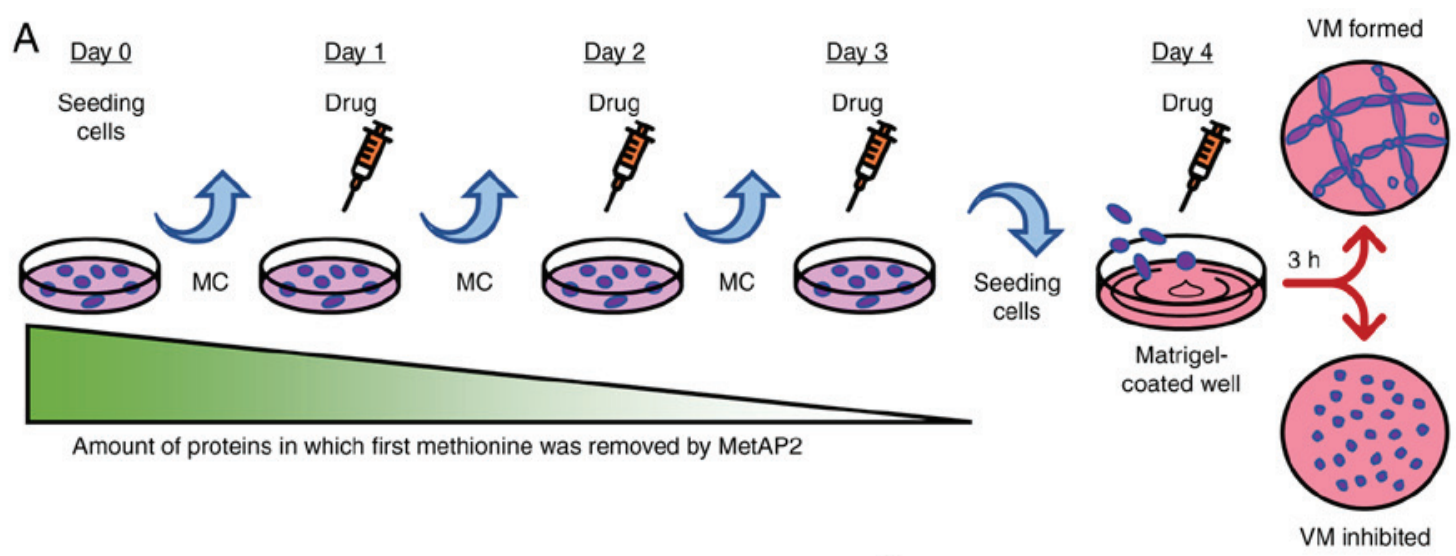

B
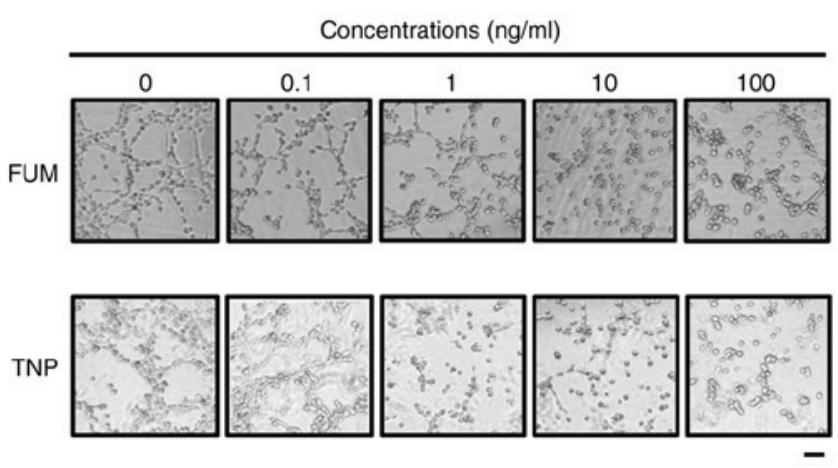

D
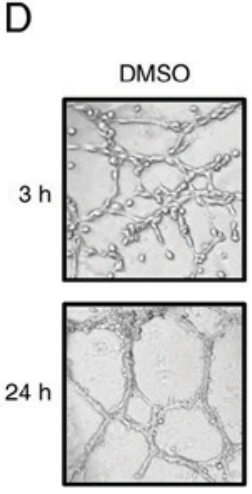
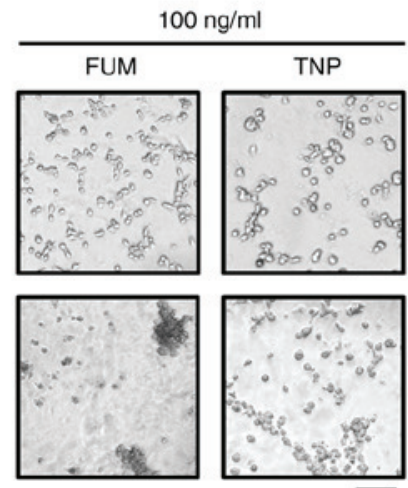

C

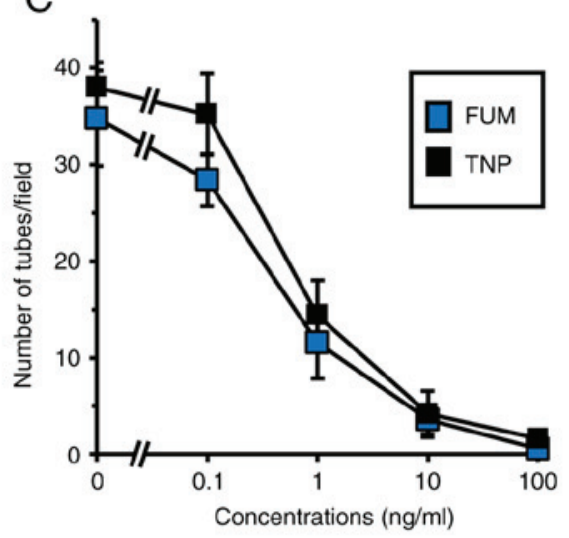

$\mathrm{E}$

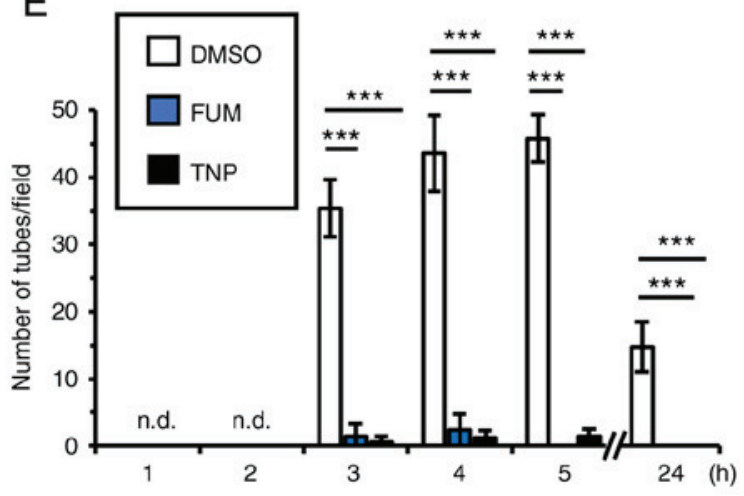

Figure 1. Fumagillin and TNP-470 inhibit VM in HT1080 cells. (A) Treatment with the MetAP2 inhibitors fumagillin (FUM) and TNP-470 (TNP). Cells were pretreated with the inhibitors for 3 consecutive days, and then experiments were performed on day 4. (B and C) MetAP2 inhibitors suppressed VM in a dose-dependent manner. HT1080 cells were treated with FUM or TNP $(0.1,1,10$, or $100 \mathrm{ng} / \mathrm{ml})$ and seeded on Matrigel-coated well plates. The quantification of VM formation was performed at $3 \mathrm{~h}$ after seeding. Scale bar, $100 \mu \mathrm{m}$. (D and E) MetAP2 inhibitors suppressed short-term and long-term VM. HT1080 cells were treated with $100 \mathrm{ng} / \mathrm{ml}$ FUM or TNP and seeded on Matrigel-coated well plates. The quantification of VM formation was performed at 3 and $24 \mathrm{~h}$ after seeding. Scale bar, $100 \mu \mathrm{m}$. Data shown are means \pm SD. n.d., not detected. ${ }^{* * *} \mathrm{P}<0.001$. VM, vasculogenic mimicry; MetAP2, methionine aminopeptidase-2.

TNP suppresses VM in several cancer cell lines. MetAP2 is central to VM in HT1080 cells. Thus, to determine whether MetAP2 is involved in VM in other types of cancer cells, we treated several types of cancer cells with TNP. As shown in Fig. 1A, upon treatment of human melanoma SK-MEL-28 and human breast cancer T47D and MDA-MB-231 cells with TNP, VM was significantly inhibited (Fig. 4). Viable cell numbers in TNP-treated cells on Matrigel were unchanged compared with the control cells (Fig. S3), confirming that the inhibition of VM was not caused by cell cytotoxicity. These results demonstrate that MetAP2 is critical for VM in human cancer cells and implicate MetAP2 inhibitors as promising therapeutics for cancer patients.

\section{Discussion}

Tumor cells acquire aggressiveness and invasiveness through various processes, such as angiogenesis and epithelial-to-mesenchymal transition (EMT), constituting targets in the development of drugs for cancer treatment $(40,41)$. Recently, vasculogenic mimicry (VM) has been indicated as a new malignant phenotype that supports tumor development $(4,10)$. In VM-positive tumors, cells take in nutrients and oxygen through their blood vessel-like tubes, rendering VM a potential novel target for antitumor therapy (42). However, the mechanisms of VM have not been detailed extensively. In the present study, we examined methionine aminopeptidase- 2 
A

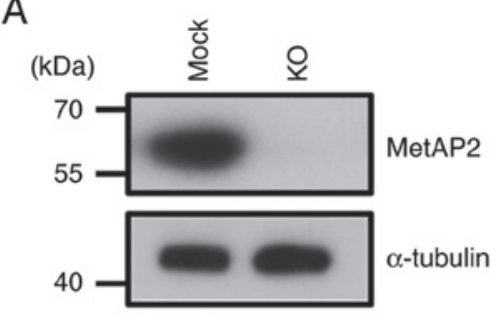

C

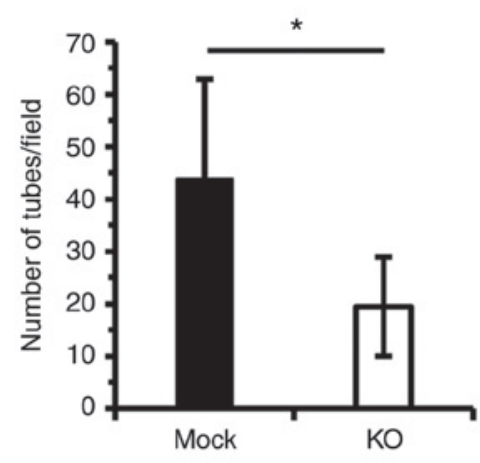

B

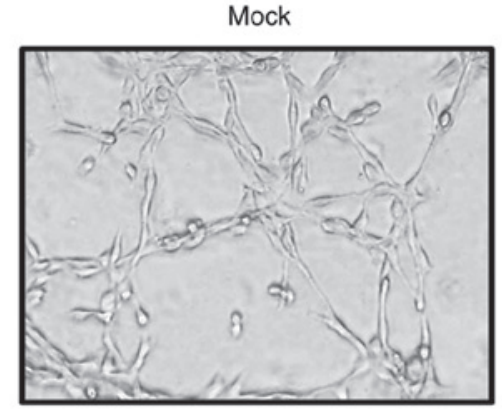

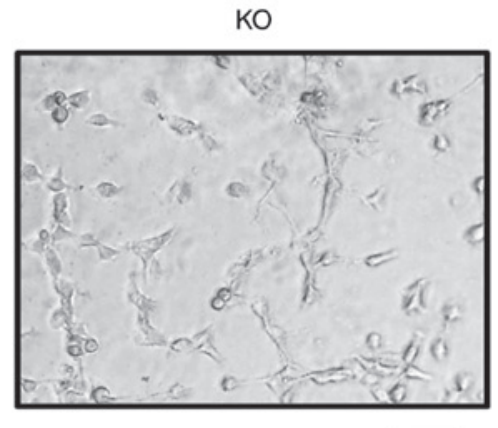

D

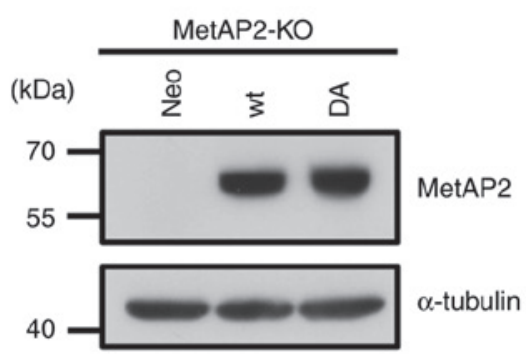

E MetAP2-KO

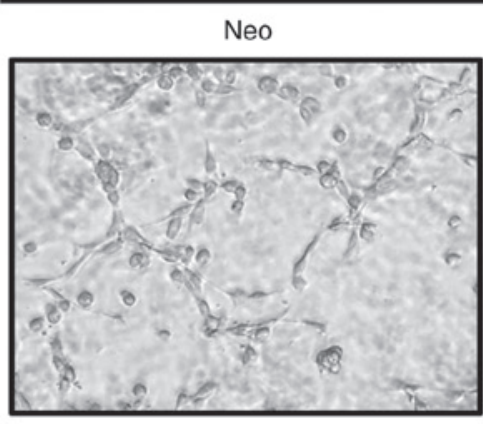

wt

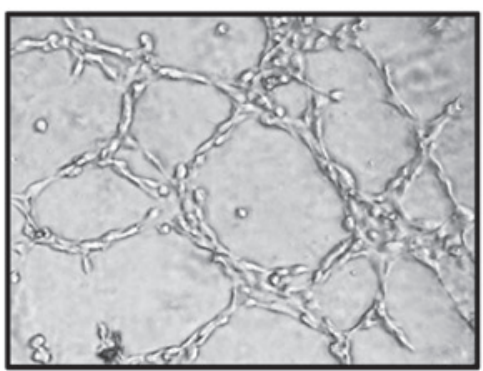

DA

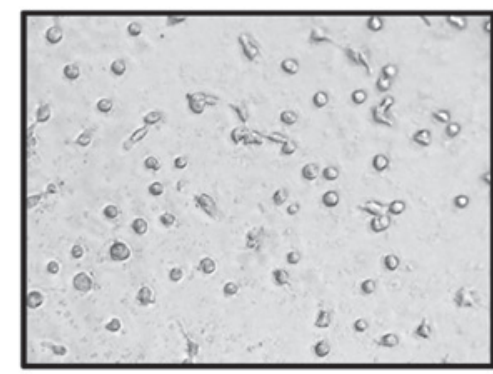

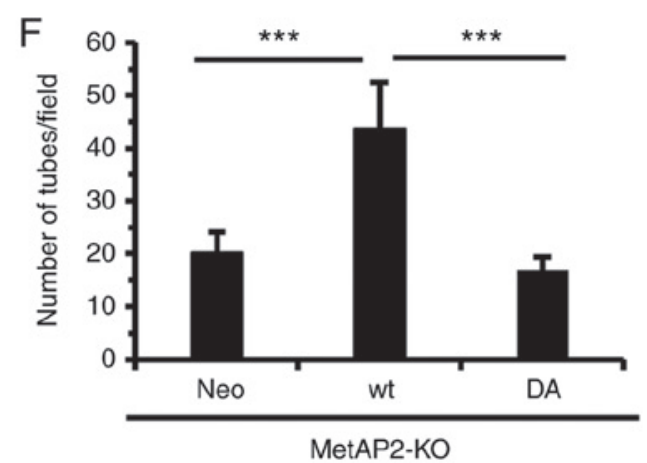

Figure 2. MetAP2 is crucial for VM in HT1080 cells. (A) Establishment of MetAP2-knockout (KO) HT1080 cell line by CRISPR/Cas9 system. (B and C) VM was abolished by KO of MetAP2. In vitro VM formation assay in MetAP2-KO HT1080 cells was performed and the tube numbers were counted at $3 \mathrm{~h}$ after seeding. Empty vector (Mock) was used as a control. Scale bar, $100 \mu \mathrm{m}$. (D) Establishment of MetAP2-re-expressing HT1080 cell lines. (E and F) Expression of wild-type (wt) but not D251A (DA) MetAP2 rescues VM. In vitro VM formation assay in wt and DA MetAP2-re-expressing HT1080 cells was performed and the tube numbers were counted at $3 \mathrm{~h}$ after seeding. Empty vector $(\mathrm{Neo})$ was used as a control. Scale bar, $100 \mu \mathrm{m}$. Data shown are means \pm SD. ${ }^{*} \mathrm{P}<0.05$, ${ }^{* * * *} \mathrm{P}<0.001$. VM, vasculogenic mimicry; MetAP2, methionine aminopeptidase-2.

(MetAP2), an important angiogenesis-related protein, and its regulation of VM in human cancer cells.

Van der Schaft et al administered the MetAP2 inhibitor TNP to several endothelial and melanoma cell lines, reporting that TNP inhibited tube formation by endothelial cells but that VM of melanoma cells was not impaired (29). In their study, TNP (100 ng/ml) was given only once; thus, we hypothesized that MetAP2 activity was not completely inhibited. To test this hypothesis, we treated human fibrosarcoma HT1080 cells with FUM and TNP for 3 consecutive days to fully suppress the effects of MetAP2 (Fig. 1A).

As a result, complete inhibition of MetAP2 disrupted VM in several cancer cell lines (Figs. 1 and 4). MetAP2 displays two major functions: removing the $\mathrm{N}$-terminal methionine 
A
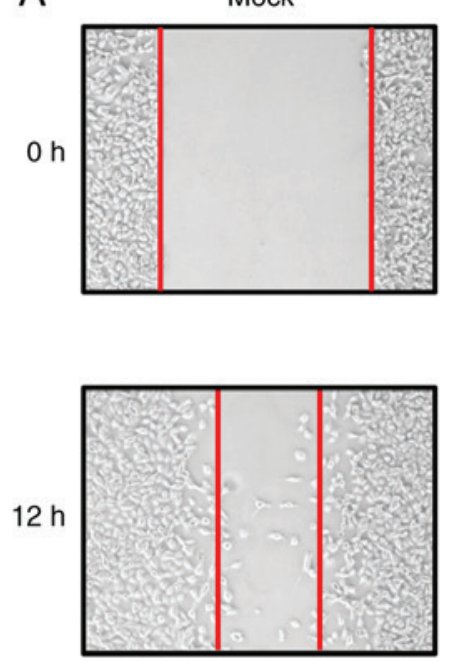

C
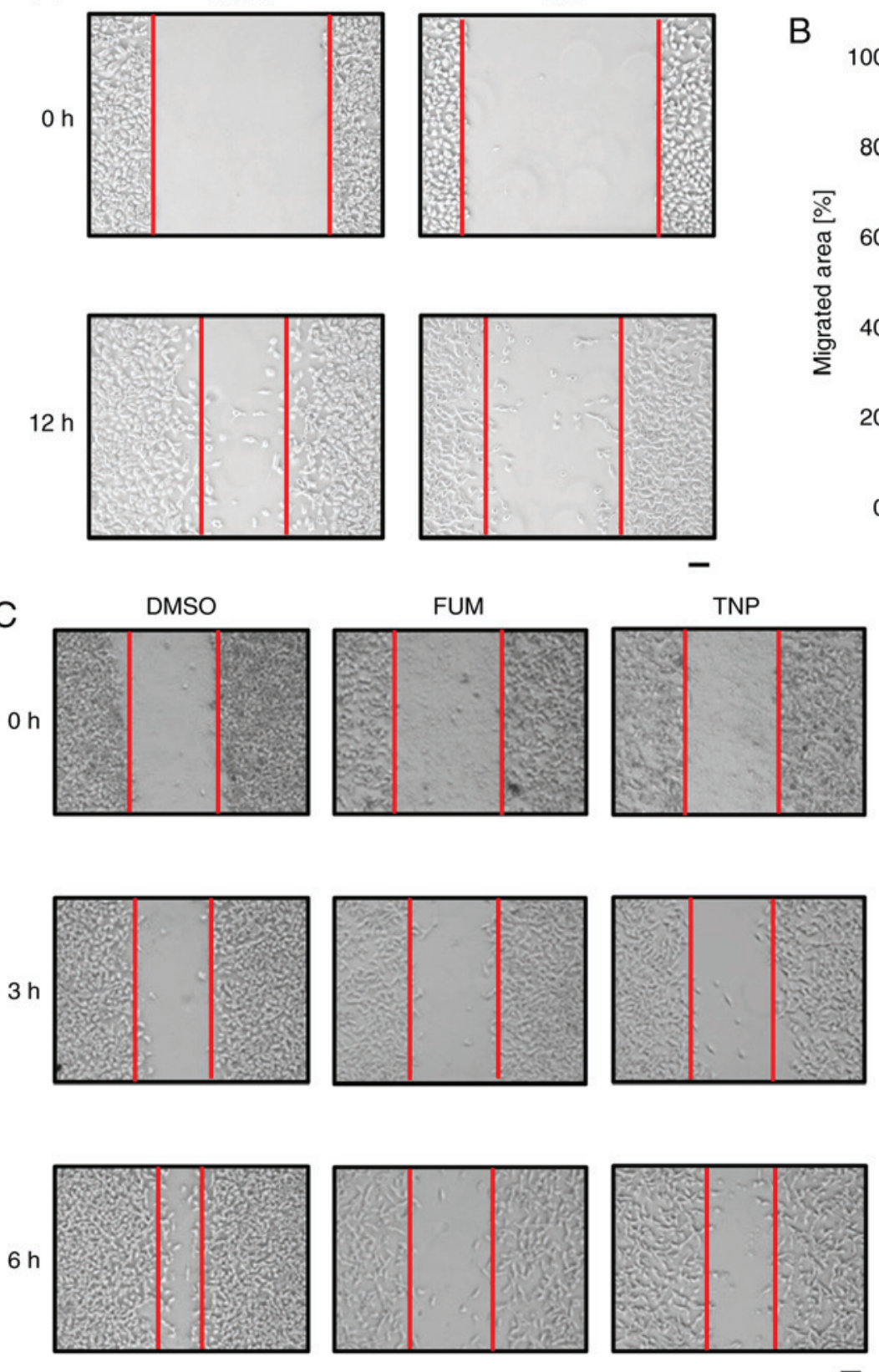

B

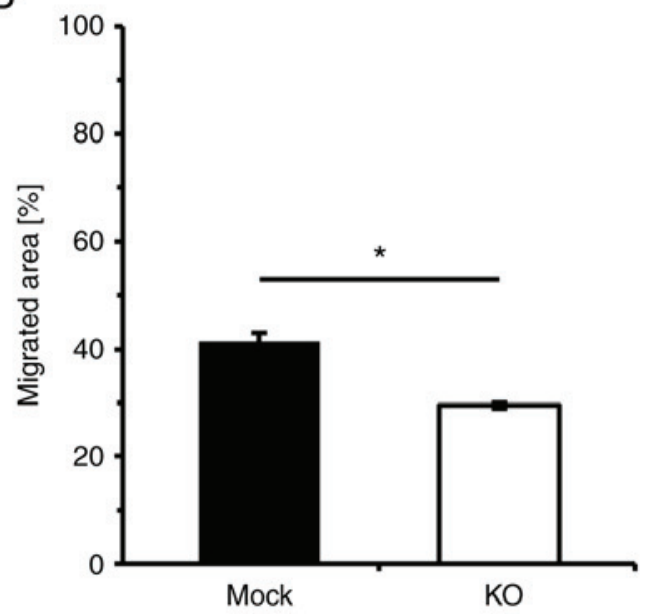

$\mathrm{D}$

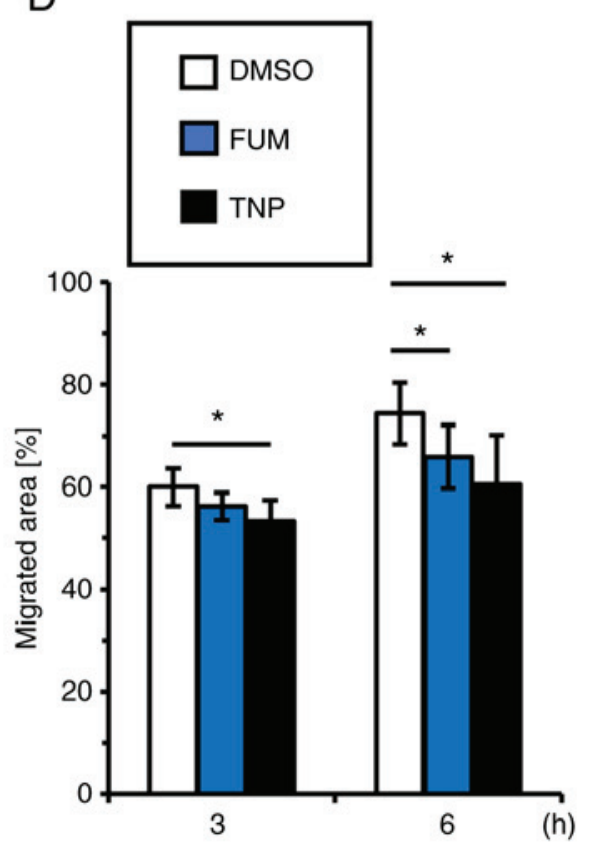

Figure 3. Inhibition of MetAP2 activity suppresses migration in HT1080 cells. (A and B) Cell migration was inhibited by knockout (KO) of MetAP2. Wound-healing assay in MetAP2-KO HT1080 cells was performed and the migrated areas were measured at $12 \mathrm{~h}$ after the scratch. Scale bar, $100 \mu \mathrm{m}$. (C and D) MetAP2 inhibitors suppress migration in HT1080 cells. Wound-healing assay in fumagillin (FUM)- or TNP-470 (TNP)-treated HT1080 cells was performed and the migrated areas were measured at 3 and $6 \mathrm{~h}$ after the scratch. Scale bar, $100 \mu \mathrm{m}$. Data shown are means $\pm \mathrm{SD}$. $\mathrm{P}<0.05$. MetAP2, methionine aminopeptidase-2.

of nascent proteins and promoting eukaryotic initiation factor $2 \alpha(\mathrm{eIF} 2 \alpha)$-mediated protein synthesis (16-18). Given that tube formation by endothelial cells was inhibited by a single TNP treatment (29), the translation of critical factors of angiogenesis might be regulated by MetAP2. Conversely, VM by cancer cells was inhibited by continuous treatment with FUM or TNP in our study. Under these conditions, the $\mathrm{N}$-terminal methionine of the substrates of MetAP2 is not cleaved, suggesting that processing by MetAP2 is pivotal for VM.

Although MetAP2 has 4 conserved amino acid residues, D251, D262, E364 and E459, D251 has been reported to influence its activity (43). The D251A MetAP2 mutant loses its autoproteolytic activity and increases the phosphorylation of eIF2 $\alpha(44,45)$; thus, protein synthesis is partially inhibited in D251A MetAP2-expressing cells. In HT1080 cells, the D251A mutation impaired the ability of MetAP2 to promote VM (Fig. 2E and F). This result indicates that eIF2 $\alpha$ regulates the translation of VM-related genes and that the inhibition of translation by mutations in MetAP2 induces a defect in the VM machinery.

In the present study, we demonstrated that MetAP2 inhibitors significantly suppressed VM in human fibrosarcoma, melanoma, and breast cancer cell lines. Using genetic methods, 
A

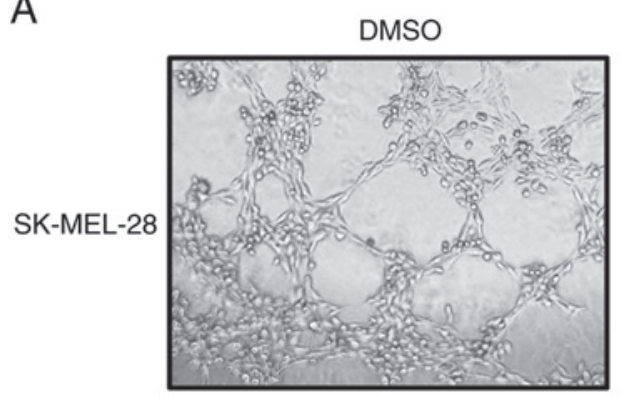

C
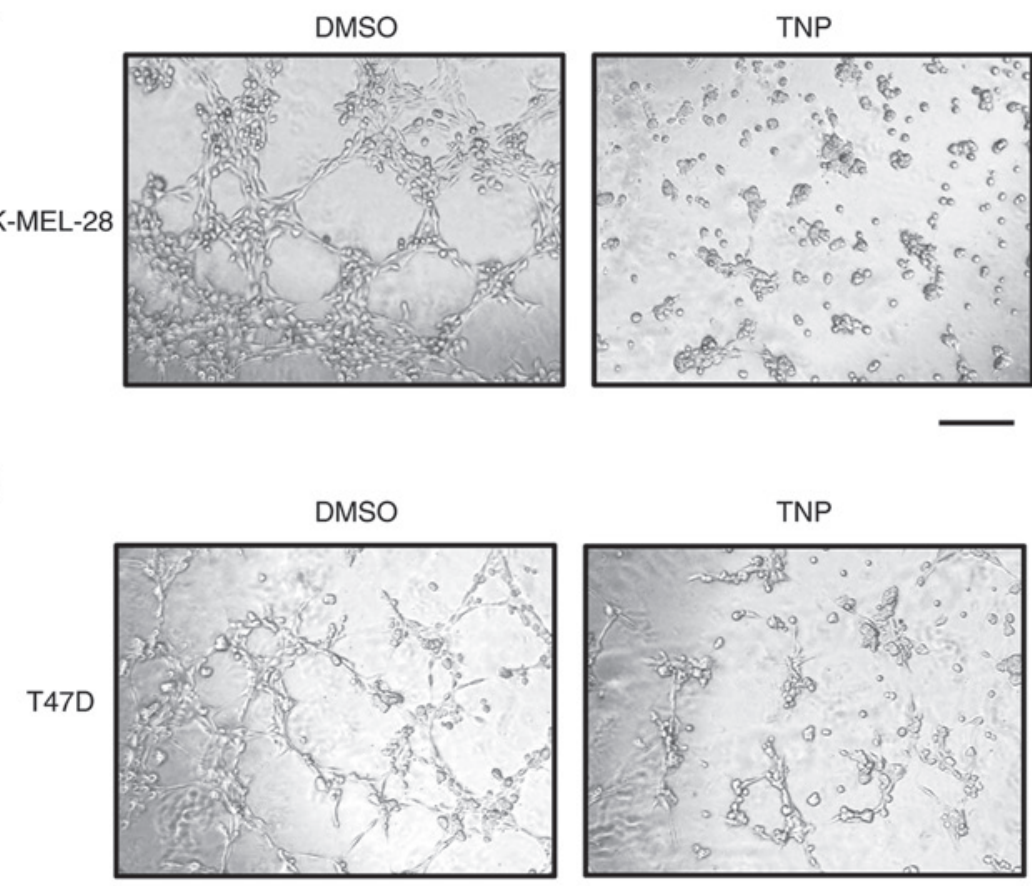

B

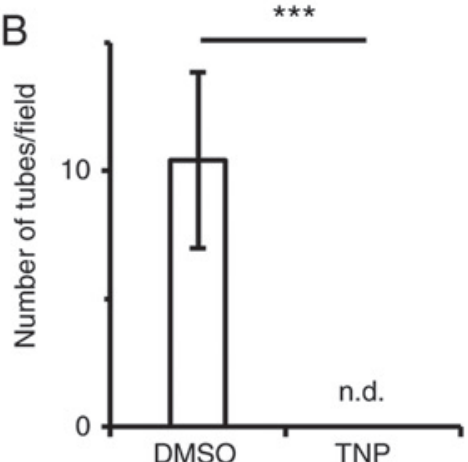

D

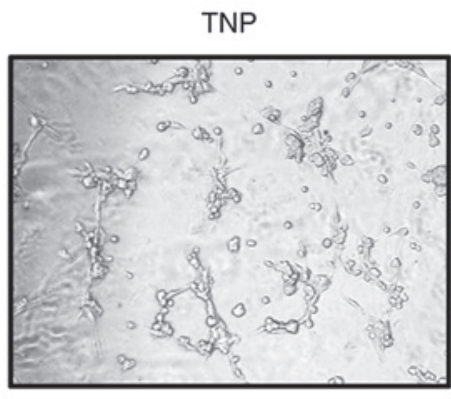

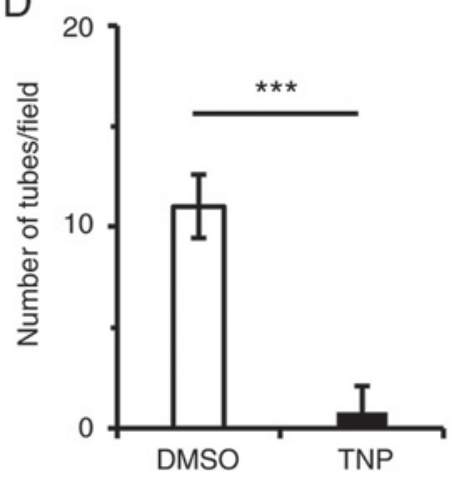

$\mathrm{F}$

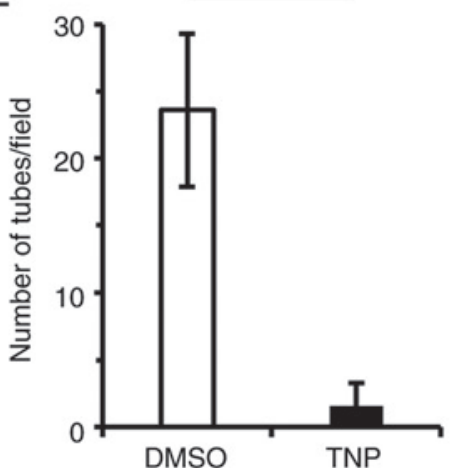

Figure 4. TNP-470 (TNP) inhibits VM in various cancer cells. (A-F) Treatment with TNP suppressed VM in human melanoma and human breast cancer cell lines: SK-MEL-28 (A), T47D, (C) and MDA-MB-231 (E) and their quantification in (B), (D), and (F), respectively. Cells were treated with 100 ng/ml TNP and seeded on Matrigel-coated well plates. The quantification of VM formation was performed at $3 \mathrm{~h}$ after seeding. Scale bars, $100 \mu \mathrm{m}$. Data shown are means \pm SD. n.d., not detected. ${ }^{* * *} \mathrm{P}<0.001$. VM, vasculogenic mimicry.

it was confirmed that the activity of MetAP2 was pivotal for VM. Thus, targeting MetAP2 might be an ideal strategy for the treatment of VM-positive cancers.

\section{Acknowledgements}

Not applicable.

\section{Funding}

This study was supported by JSPS KAKENHI (grant no. JP20J11197).

\section{Availability of data and materials}

The datasets of this study are available from the corresponding author on reasonable request.

\section{Authors' contributions}

SShi, RK and SSim designed the study. SSim performed all of the experiments. SShi, RK and SSim wrote the original draft. All authors confirmed the accuracy of the data, read and approved the manuscript and agree to be accountable for all aspects of the research in ensuring that the accuracy or integrity of any part of the work are appropriately investigated and resolved.

\section{Ethics approval and consent to participate}

Not applicable.

\section{Patient consent for publication}

Not applicable. 


\section{Competing interests}

The authors declare that they have no competing interests.

\section{References}

1. Folkman J: Role of angiogenesis in tumor growth and metastasis. Semin Oncol 29 (6 Suppl 16): S15-S18, 2002.

2. Folkman J: Angiogenesis: An organizing principle for drug discovery? Nat Rev Drug Discov 6: 273-286, 2007.

3. Aalders KC, Tryfonidis K, Senkus E and Cardoso F: Anti-angiogenic treatment in breast cancer: Facts, successes, failures and future perspectives. Cancer Treat Rev 53: 98-110, 2017.

4. Maniotis AJ, Folberg R, Hess A, Seftor EA, Gardner LM, Pe'er J, Trent JM, Meltzer PS and Hendrix MJ: Vascular channel formation by human melanoma cells in vivo and in vitro: Vasculogenic mimicry. Am J Pathol 155: 739-752, 1999.

5. Wei X, Chen Y, Jiang X, Peng M, Liu Y, Mo Y, Ren D, Hua Y, $\mathrm{Yu} \mathrm{B}$, Zhou Y, et al: Mechanisms of vasculogenic mimicry in hypoxic tumor microenvironments. Mol Cancer 20: 7, 2021.

6. Williamson SC, Metcalf RL, Trapani F, Mohan S, Antonello J, Abbott B, Leong HS, Chester CP, Simms N, Polanski R, et al: Vasculogenic mimicry in small cell lung cancer. Nat Commun 7 : 13322,2016

7. Shirakawa K, Tsuda H, Heike Y, Kato K, Asada R, Inomata M, Sasaki H, Kasumi F, Yoshimoto M, Iwanaga T, et al: Absence of endothelial cells, central necrosis, and fibrosis are associated with aggressive inflammatory breast cancer. Cancer Res 61 : 445-451, 2001

8. Wagenblast E, Soto M, Gutiérrez-Ángel S, Hartl CA, Gable AL, Maceli AR, Erard N, Williams AM, Kim SY, Dickopf S, et al: A model of breast cancer heterogeneity reveals vascular mimicry as a driver of metastasis. Nature 520: 358-362, 2015.

9. Cao Z, Bao M, Miele L, Sarkar FH, Wang Z and Zhou Q: Tumour vasculogenic mimicry is associated with poor prognosis of human cancer patients: A systemic review and meta-analysis. Eur J Cancer 49: 3914-3923, 2013.

10. Yang JP, Liao YD, Mai DM, Xie P, Qiang YY, Zheng LS, Wang MY, Mei Y, Meng DF, Xu L, et al: Tumor vasculogenic mimicry predicts poor prognosis in cancer patients: A metaanalysis. Angiogenesis 19: 191-200, 2016.

11. Li W, Zong S, Shi Q, Li H, Xu J and Hou F: Hypoxia-induced vasculogenic mimicry formation in human colorectal cancer cells: Involvement of HIF-1a, Claudin-4, and E-cadherin and Vimentin. Sci Rep 6: 37534, 2016.

12. Wang M, Zhao X, Zhu D, Liu T, Liang X, Liu F, Zhang Y, Dong X and Sun B: HIF-1 $\alpha$ promoted vasculogenic mimicry formation in hepatocellular carcinoma through LOXL2 up-regulation in hypoxic tumor microenvironment. J Exp Clin Cancer Res 36: 60, 2017.

13. Bergers G, Brekken R, McMahon G, Vu TH, Itoh T, Tamaki K, Tanzawa K, Thorpe P, Itohara S, Werb Z and Hanahan D: Matrix metalloproteinase-9 triggers the angiogenic switch during carcinogenesis. Nat Cell Biol 2: 737-744, 2000.

14. Meng J, Chen S, Lei YY, Han JX, Zhong WL, Wang XR, Liu YR, Gao WF, Zhang Q, Tan Q, et al: Hsp90 $\beta$ promotes aggressive vasculogenic mimicry via epithelial-mesenchymal transition in hepatocellular carcinoma. Oncogene 38: 228-243, 2019.

15. Cai HP, Wang J, Xi SY, Ni XR, Chen YS, Yu YJ, Cen ZW, Yu ZH, Chen FR, Guo CC, et al: Tenascin-c mediated vasculogenic mimicry formation via regulation of MMP2/MMP9 in glioma. Cell Death Dis 10: 879, 2019.

16. Chang YH, Teichert U and Smith JA: Molecular cloning, sequencing, deletion, and overexpression of a methionine aminopeptidase gene from Saccharomyces cerevisiae. J Biol Chem 267: $8007-8011,1992$

17. Li X and Chang YH: Amino-terminal protein processing in Saccharomyces cerevisiae is an essential function that requires two distinct methionine aminopeptidases. Proc Natl Acad Sci USA 92: 12357-12361, 1995.

18. Datta B, Chakrabarti D, Roy AL and Gupta NK: Roles of a $67-\mathrm{kDa}$ polypeptide in reversal of protein synthesis inhibition in heme-deficient reticulocyte lysate. Proc Natl Acad Sci USA 85: 3324-3328, 1988

19. McCowen MC, Callender ME and Lawlis JF Jr: Fumagillin (H-3), a new antibiotic with amebicidal properties. Science 113: 202-203, 1951
20. Ingber D, Fujita T, Kishimoto S, Sudo K, Kanamaru T, Brem H and Folkman J: Synthetic analogues of fumagillin that inhibit angiogenesis and suppress tumour growth. Nature 348: 555-557, 1990.

21. Kusaka M, Sudo K, Matsutani E, Kozai Y, Marui S, Fujita T, Ingber D and Folkman J: Cytostatic inhibition of endothelial cell growth by the angiogenesis inhibitor TNP-470 (AGM-1470). Br J Cancer 69: 212-216, 1994

22. Sin N, Meng L, Wang MQ, Wen JJ, Bornmann WG and Crews CM: The anti-angiogenic agent fumagillin covalently binds and inhibits the methionine aminopeptidase, MetAP-2. Proc Natl Acad Sci USA 94: 6099-6103, 1997.

23. Griffith EC, Su Z, Turk BE, Chen S, Chang YH, Wu Z, Biemann K and Liu JO: Methionine aminopeptidase (type 2) is the common target for angiogenesis inhibitors AGM-1470 and ovalicin. Chem Biol 4: 461-471, 1997.

24. Yeh JJ, Ju R, Brdlik CM, Zhang W, Zhang Y, Matyskiela ME, Shotwell JD and Crews CM: Targeted gene disruption of methionine aminopeptidase 2 results in an embryonic gastrulation defect and endothelial cell growth arrest. Proc Natl Acad Sci USA 103: 10379-10384, 2006.

25. Catalano A, Romano M, Robuffo I, Strizzi L and Procopio A: Methionine aminopeptidase-2 regulates human mesothelioma cell survival: Role of Bcl-2 expression and telomerase activity. Am J Pathol 159: 721-731, 2001.

26. Selvakumar P, Lakshmikuttyamma A, Kanthan R, Kanthan SC, Dimmock JR and Sharma RK: High expression of methionine aminopeptidase 2 in human colorectal adenocarcinomas. Clin Cancer Res 10: 2771-2775, 2004.

27. Tucker LA, Zhang Q, Sheppard GS, Lou P, Jiang F, McKeegan E, Lesniewski R, Davidsen SK, Bell RL and Wang J: Ectopic expression of methionine aminopeptidase-2 causes cell transformation and stimulates proliferation. Oncogene 27: 3967-3976, 2008.

28. Wang J, Sheppard GS, Lou P, Kawai M, BaMaung N, Erickson SA, Tucker-Garcia L, Park C, Bouska J, Wang YC, et al: Tumor suppression by a rationally designed reversible inhibitor of methionine aminopeptidase-2. Cancer Res 63: 7861-7869, 2003.

29. Van der Schaft DW, Seftor RE, Seftor EA, Hess AR, Gruman LM, Kirschmann DA, Yokoyama Y, Griffioen AW and Hendrix MJ: Effects of angiogenesis inhibitors on vascular network formation by human endothelial and melanoma cells. J Natl Cancer Inst 96: 1473-1477, 2004.

30. Kawahara R, Niwa Y and Simizu S: Integrin $\beta 1$ is an essential factor in vasculogenic mimicry of human cancer cells. Cancer Sci 109: 2490-2496, 2018

31. Ran FA, Hsu PD, Wright J, Agarwala V, Scott DA and Zhang F: Genome engineering using the CRISPR-Cas9 system. Nat Protoc 8: 2281-2308, 2013.

32. Simizu S, Umezawa K, Takada M, Arber $\mathrm{N}$ and Imoto $\mathrm{M}$ : Induction of hydrogen peroxide production and Bax expression by caspase-3(-like) proteases in tyrosine kinase inhibitor-induced apoptosis in human small cell lung carcinoma cells. Exp Cell Res 238: 197-203, 1998.

33. Yasukagawa T, Niwa Y, Simizu S and Umezawa K: Suppression of cellular invasion by glybenclamide through inhibited secretion of platelet-derived growth factor in ovarian clear cell carcinoma ES-2 cells. FEBS Lett 586: 1504-1509, 2012.

34. Komai K, Niwa Y, Sasazawa Y and Simizu S: Pirin regulates epithelial to mesenchymal transition independently of Bcl3-Slug signaling. FEBS Lett 589: 738-743, 2015.

35. Katsuyama S, Sugino K, Sasazawa Y, Nakano Y, Aono H, Morishita K, Kawatani M, Umezawa K, Osada H and Simizu S: Identification of a novel compound that inhibits osteoclastogenesis by suppressing nucleoside transporters. FEBS Lett 590: $1152-1162,2016$

36. Ishida K, Wierzba MK, Teruya T, Simizu S and Osada H: Novel heparan sulfate mimetic compounds as antitumor agents. Chem Biol 11: 367-377, 2004.

37. Schneider CA, Rasband WS and Eliceiri KW: NIH Image to ImageJ: 25 years of image analysis. Nat Methods 9: 671-675, 2012.

38. Simizu S, Imoto $\mathrm{M}$ and Umezawa $\mathrm{K}$ : Induction of apoptosis by erbstatin in mouse leukemia L1210 cells. Biosci Biotechnol Biochem 58: 1549-1552, 1994.

39. Griffith EC, Su Z, Niwayama S, Ramsay CA, Chang YH and Liu JO: Molecular recognition of angiogenesis inhibitors fumagillin and ovalicin by methionine aminopeptidase 2. Proc Natl Acad Sci USA 95: 15183-15188, 1998.

40. Kerbel RS: Tumor angiogenesis. N Engl J Med 358: 2039-2049, 2008. 
41. Davis FM, Stewart TA, Thompson EW and Monteith GR Targeting EMT in cancer: Opportunities for pharmacological intervention. Trends Pharmacol Sci 35: 479-488, 2014.

42. Delgado-Bellido D, Serrano-Saenz S, Fernández-Cortés M and Oliver FJ: Vasculogenic mimicry signaling revisited: Focus on non-vascular VE-cadherin. Mol Cancer 16: 65, 2017.

43. Datta B, Majumdar A, Datta R and Balusu R: Treatment of cells with the angiogenic inhibitor fumagillin results in increased stability of eukaryotic initiation factor 2-associated glycoprotein, p67, and reduces phosphorylation of extracellular signal-regulated kinases. Biochemistry 43: 14821-14831, 2004
44. Datta B and Datta R: Mutation at the acidic residue-rich domain of eukaryotic initiation factor 2 (eIF2alpha)-associated glycoprotein p67 increases the protection of eIF2alpha phosphorylation during heat shock. Arch Biochem Biophys 413: 116-122, 2003.

45. Datta B, Ghosh A, Majumdar A and Datta R: Autoproteolysis of rat p67 generates several peptide fragments: The N-terminal fragment, p26, is required for the protection of eIF2alpha from phosphorylation. Biochemistry 46: 3465-3475, 2007.

This work is licensed under a Creative Commons

Attribution-NonCommercial-NoDerivatives 4.0 International (CC BY-NC-ND 4.0) License. 